\title{
HAMA-HAMA PADA TANAMAN PADI SAWAH (Oryza sativa L.) DI KELURAHAN MAKALONSOW KECAMATAN TONDANO TIMUR KABUPATEN MINAHASA
}

\section{PESTS ON RICE FIELD CROPS (Oryza sativa L.) IN THE MAKALONSOW VILLAGE OF EAST TONDANO DISTRICT IN MINAHASA REGENCY}

\author{
Jusuf Manueke1), Berty H. Assa1), dan Evangeline A. Pelealu2) \\ 1)Dosen Fakultas Pertanian Universitas Sam Ratulangi (UNSRAT) \\ 2)Dosen Fakultas IImu Sosial Universitas Negeri Manado (UNIMA)
}

\begin{abstract}
The purpose of this research is to know the pest species in wetland rice crops at Makalonsow Village of East Tondano Distric in Minahasa Regency. The study used a descriptive obsevational method that is observing directly the pests found in rice paddy fields by means of sweeping with insect net and observing directly on paddy fields plaot and paddy fields clumps. The identified pests were identified and made in accordance with the results of identification for each species of pest. The results showed that 11 species of pests and 4 spesies of natural enemies found in paddy fields of wetland rice at Makalonsow Village of East Tondano District in Minahasa Regency. The pests are White Rice Stem Borer (Tryporyza innotata), Rice Cherry Stem Borer (Chilo suppressalis), Purple Rice Stem Borer (Sesamia inferens), White Pest (Nymphula depunctalis), Brown Planthopper (Nephotettix virescens), Green Planthopper (Nilaparvata lugens), Paddy Stink Bug (Leptocorisa acuta), Black Lady Bug (Pareaucosmetus sp.), Rice Weevil (Sitophilus oryzae), Golden Snail (Pomacea caniculata), Hous and Tre Sparow (Passer spp.), and Rice-field Rat (Ratus argentiventer.). Natural enemies are Worship Grasshopper (Mantis sp.), Dragonflies (Sympetrum flaveolum), Coccinelid Beetle (Coccinella septempunctata), and Spider Hunters (Pardosa sp.).
\end{abstract}

Keywords : plant pest, wetland rice crops, natural enemies of pest

\begin{abstract}
ABSTRAK
Tujuan penelitian adalah mengetahui jenis-jenis hama pada tanaman padi sawah di Kelurahan Makalonsow Kecamatan Tondano Timur Kabupaten Minahasa. Penelitian menggunakan metode obsevasional deskriptif yaitu mengamati langsung hama yang ditemukan pada areal tanaman padi sawah dengan cara penyapuan dengan net serangga dan mengamati langsung pada petakan sawah dan rumpun tanaman padi sawah. Hama-hama yang ditemukan diidentifikasi dan dibuat deskripsi sesuai dengan hasil identifikasi untuk setiap jenis hama. Hasil penelitian menunjukkan bahwa ditemukan 11 jenis hama dan 4 jenis musuh alami padahabitat tanaman padi sawah di Kelurahan Makalonsow Kecamatan Tondano Timur Kabupaten Minahasa. Hama-hama tersebut yaitu Penggerek batang padi putih (Tryporyza innotata), Penggerek Batang Padi Bergaris (Chilo suppressalis), Penggerek Batang Padi Ungu (Sesamia inferens), Hama Putih (Nymphula depunctalis), Wereng Coklat (Nephotettix virescens), Wereng Hijau (Nilaparvata lugens), Walang Sangit (Leptocorisa acuta), Kepik Hitam (Pareaucosmetus sp.), Bubuk Beras (Sitophilus oryzae), Keong Emas (Pomacea caniculata), Hama Burung Padi Sawah (Passer spp.), dan Hama Tikus Sawah (Ratus argentiventer). Musuh alami yaitu Belalang Sembah (Mantis sp.), Capung (Sympetrum flaveolum), Kumbang Coccinelid (Coccinella septempunctata), dan Laba-Laba Pemburu (Pardosa sp.).

Kata kunci : hama tanaman, tanaman padi sawah, musuh alamiah hama
\end{abstract}

Eugenia Volume 23 No. 3 Oktober 2017 


\section{PENDAHULUAN}

Kelurahan Makalonsow merupakan salah satu kelurahan yang ada di Kecamatan Tondano Timur Kabupaten Minahasa. Secara umum, wilayah Kecamatan Tondano Timur dapat dibedakan dalam tiga satuan geomorphologi yakni dataran/sawah, perbukitan/ladang dan pegunungan/hutan. Luas areal pertanian di Kelurahan Makalonsow yaitu 153 ha yang teridiri dari 94 ha sawah dan 59 ha perkebunan/ladang. Areal persawahan terdiri dari 73 ha sawah tadah hujan dan 21 ha sawah irigasi teknis (Pelealu, 2015).

Usaha pertanian padi sawah sudah dilakukan oleh masyarakat Kelurahan Makalonsow sejak dari nenek moyang secara turun-temurun kepada anak, cucu, cece, cicit, bahkan sampai saat pelaksanaan penelitian ini. Kegiatan usaha padi sawah masih dilakukan secara konvensional dan belum banyak mengadopsi teknologi pertanian modern. Kegiatan budidaya tanaman padi sawah masih dilakukan secara gotong royong (Pelealu, 2015).

Sampai saat ini ternyata usaha tani padi sawah di Kelurahan Makalonsow banyak mengalami kendala di lapangan, terutama serangan organisme pengganggu tanaman (OPT) yang meliputi hama dan penyakit tanaman. Hama-hama yang banyak ditemui menyerang tanaman padi sawah antara lain penggerek batang padi (Sesami ainferens, Chilo supresalis, Triporiza innotata, Nympula depuntalis dan Scircophaga incertulas. ), hama wereng coklat dan hijau (Nilaparvat alugens dan Nepotetix apicalis), walang sangit (Leptocorixa acuta), hama lembing hijau (Nezaraviridula), keong mas (Pomacea canaliculata), tikus (Ratus-ratus $\mathrm{sp}$ ) dan hama unggas (burung) (Kalshoven, 1981; Pathak, 1977; Sembel, dkk., 2000).

Sama halnya dengan kegiatan bercocok tanam yaitu penyiapan benih, penyemaian, pengolahan tanah, penanaman, pemupukan penyiangan dan panen yang masih didominasi oleh cara konvensional, pengendalian hama dan penyaikit juga masih dilakukan secara konvensional yaitu hanya mengandalkan pengendalian kimia yaitu penggunaan kimia sintetis yang dapat mencemari lingkungan (tanah, air, udara, dan tanaman), menyebabkan hama menjadi resisten, dan terjadi resurgensi hama. Belum dilakukan pengendalian hama yang ramah lingkungan yaitu pengendalian hama secara terpadu (PHT) sehingga kerusakan yang diakibatkan oleh hama dan penyakit pada tanaman padi sawah masih tinggi (Southwood and Woy, 1970; Flint and van den Bosch, 1981; Heinrichs, 1994; Oka, 1995; Roja, 2009; Untung, 2001; Guntoro, 2011).

Penelitian ini sangat urgen dilakukan untuk mendapatkan data dan informasi mengenai hamahama dan musuh alamiah hama tanaman padi sawah karena sangat membantu petani Kelurahan Makalonsow dalam mengatasi permasalahan dalam usaha tani padi sawah yaitu menyusun cara dan srategi pengendalian, terutam hama tanaman padi sawah. Tujuan penelitian adalah mengetahui jenis-jenis hama pada tanaman padi sawah di Kelurahan Makalonsow Kecamatan Tondano Timur Kabupaten Minahasa.

\section{METODE PENELITIAN}

Penelitian dilaksanakan di kebun sawah milik petani di Kelurahan Makalonsow Kecamatan Tondano Timur Kabupaten Minahasa. Lama pelaksanaan penelitian yaitu tiga bulan, dari bulan Mei sampai dengan bulan Juli 2017. Penelitian menggunakan metode observasional deskriptif yaitu mengambil sampel jenis-jenis hama pada areal pertanaman padi sawah dengan cara penyapuan dengan net serangga dan mengamati langsung pada petakan sawah dan rumpun tanaman padi sawah. Hama-hama yang ditemukan diidentifikasi menggunakan kunci identifikasi, koleksi yang ada di laboratorium hama tumbuhan serta referensireferensi pendukung lainnya. Jenis-jenis hama yang sudah teridentifikasi dibuat deskripsi sesuai dengan karakter morfologi dari setiap jenis hama.

\section{HASIL DAN PEMBAHASAN}

Hasil identifikasi sampel yang diperoleh pada areal partanaman padi sawah di Kelurahan Makalonsow Kecamatan Tondano Timur Kabupaten Minahasa menunjukkan bahwa selain jenis-jenis hama, ditemukan juga musuh-musuh 
alami hama. Jenis-jenis hama dan musuh alami hama yang ditemukan di Kelurahan Makalonsow Kecamatan Tondano Timur Kabupaten Minahasa dapat diikuti pada Tabel 1.

Data pada tabel 1 menunjukkan bahwa terdapat 11 jenis hama dan 4 jenis musuh alami pada habitat tanaman padi sawah di Kelurahan Makalonsow Kecamatan Tondano Timur Kabupaten Minahasa. Hama-hama tersebut adalah Scirpophaga innotata dengan nama lokal penggerek batang padi putih, Chilo suppressalis nama lokal penggerek batang padi bergaris, Nymphula depunctalis nama lokal hama putih, Sesamia inferens nama lokal penggerek batang padi ungu, Nephotettix virescens nama lokal wereng coklat, Nilaparvata lugens nama lokal wereng hijau, Leptocorisa acuta nama lokal walang sangit, Pareaucosmetus sp nama lokal kepik hitam, Sitophilus oryzae nama lokal bubuk beras, Pomacea caniculata nama lokal keong emas Passer spp. nama lokal hama burung padi sawah atau hama ringkeng dan Ratus argentiventer nama lokal hama tikus padi sawah atau kawok. Musuh alami adalah Mantis sp nama lokal belalang sembah atau tunjung langit, Sympetrum flaveolum nama lokal capung atau peret; Coccinella septempunctata nama lokal kumbang coccinelid, dan Pardosa sp. nama lokal laba-laba pemburu.

Deskripsi hama-hama yang ditemukan pada tanaman padi sawah di Desa Makalonsow Kecamatan Tondano Timur adalah sebagai berikut :

Tabel 1. Hama-hama dan Musuh Alamiah yang Ditemukan pada Habitat Pertanaman Padi Sawah di Kelurahan Makalonsow Kecamatan Tondano Timur Kabupaten Minahasa

(Table 1. Pests and Natural Enemies Found in Rice Planting Habitats in Makalonsow Village of East Tondano District in Minahasa Regency)

\begin{tabular}{|c|c|c|c|c|c|c|}
\hline $\begin{array}{l}\text { No. } \\
11 .\end{array}$ & \multirow{2}{*}{\begin{tabular}{l}
\multicolumn{1}{c}{ Filum/Kelas } \\
Athropoda/ \\
Insekta
\end{tabular}} & \multirow{2}{*}{$\begin{array}{r}\text { Ordo } \\
\text { Lepidoptera }\end{array}$} & \multicolumn{2}{|r|}{ Famili } & \multirow{2}{*}{$\begin{array}{c}\text { Jenis/Spesies } \\
\text { Scirpophaga innotata }\end{array}$} & \multirow{2}{*}{$\begin{array}{l}\text { Status } \\
\text { Hama }\end{array}$} \\
\hline \multirow[t]{12}{*}{1.} & & & 1) & Pyralidae & & \\
\hline & & & 2) & Pyralidae & Chilo suppressalis & Hama \\
\hline & & & 3) & Pyralidae & Nymphula depunctalis & Hama \\
\hline & & & 4) & Nuctuidae & Sesamia inferens & Hama \\
\hline & & Homoptera & 1) & Jassidae & Nephotettix virescens & Hama \\
\hline & & & 2) & Delphacidae & Nilaparvata lugens & Hama \\
\hline & & Hemiptera & 1) & Alydidae & Leptocorisa acuta & Haam \\
\hline & & & 2) & Lygaeidae & Pareaucosmetus sp & Hama \\
\hline & & Coleoptera & 1) & Coccinelidae & $\begin{array}{l}\text { Coccinella } \\
\text { septempunctata }\end{array}$ & $\begin{array}{l}\text { Musuh } \\
\text { alamiah }\end{array}$ \\
\hline & & & 2) & Cucurlionidae & Sitophilus oryzae L & Hama \\
\hline & & Orthoptera & & tidae & Mantis sp. & $\begin{array}{l}\text { Musuh } \\
\text { alamiah }\end{array}$ \\
\hline & & Odonata & & ellulidae & Sympetrum flaveolum & $\begin{array}{l}\text { Musuh } \\
\text { alamiah }\end{array}$ \\
\hline 2 & $\begin{array}{l}\text { Molluscal } \\
\text { Gastropoda }\end{array}$ & Megastropoda & & ullariidae & Pomacea caniculata & Hama \\
\hline 3. & $\begin{array}{l}\text { Arthropoda/ } \\
\text { Arahnida }\end{array}$ & Araneae & & sidae & Pardosa sp. & $\begin{array}{l}\text { Musuh } \\
\text { alamiah }\end{array}$ \\
\hline 4. & Aves & Passeriformes & & seridae & Passerspp. & Hama \\
\hline 5. & Mamalia & Rodentia & $\mathrm{Mu}$ & dae & Ratus argentiventer. & Hama \\
\hline
\end{tabular}




\section{Scirpophaga innotata Walker (Pyralidae)}

Imago berbentuk ngengt, berwarna putih, panjang tubuh 12,5-14 mm (Gambar 1).

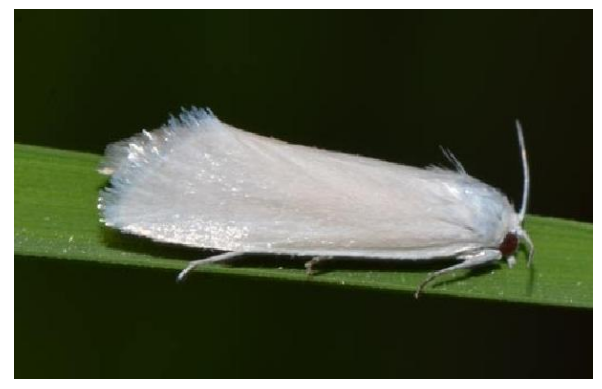

Gambar 1. Imago Scirpophaga innotata Walker

(Figure 1. The Adult of Scirpophaga innotata Walker)

Serangan hama ini dapat menyebabkan gejala sundep pada tanaman padi sawah yaitu larva menyerang pangkal daun muda kemudian menjadi layu dan mengering. Jika menyerang batang maka menyebabkan gejalah beluk yaitu larva menyerang batang pada waktu awal pembungaan sehingga menyebabkan bulir menjadi hampa dan tangkai bulir padi dapat dicabut dengan mudah.

\section{Chilo suppressalis Walker (Lepidoptera: Pyralidae)}

Imago berwarna seperti jerami, coklat mudah dan memiliki sisik berwarna perak. Panjang tubuh 4,5 - 5,5 mm (Gambar 2).

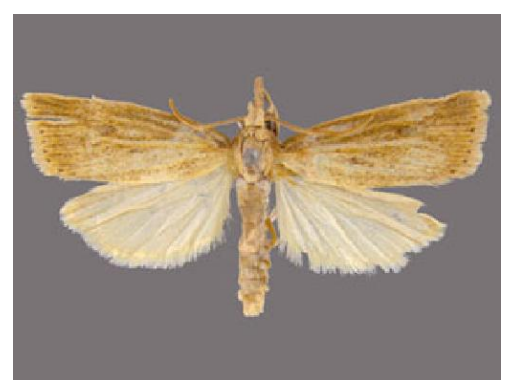

Gambar 2. Imago Chilo suppressalis

(Figure 2. The Adult of Chilo suppressalis)

Larva menyerang daun, pelepah dan batang. Serangan pada daun dan pelepah menyebabkan adanya bercak coklat daun dan pelepah, dan lama kelamaan menjadi kering. Serang- an pada batang menyebabkan batang berlubang dan mudah patah dan bulirnya tidak berisi atau hampah.

\section{Nymphula depunctalis Guenee (Lepidoptera: Pyralidae)}

Imago berwarna putih krem, dengan 2 buah titik hitam dan bercak berwarna kecoklatan. Ukuran tubuh 5,5 - $7 \mathrm{~mm}$ dan rentang sayap 14 $16 \mathrm{~mm}$ (Gambar 3).

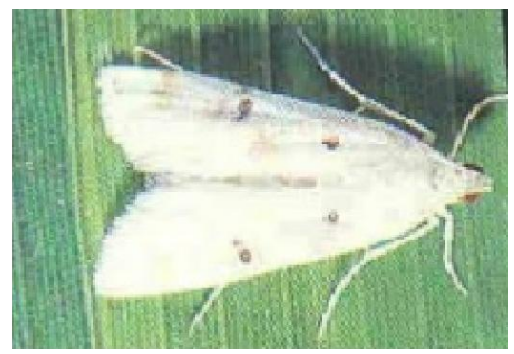

Gambar 3. Imago Nymphula depunctalis Guenee

(Figure 3. The Aadult of Nymphula depunctalis Guenee)

Serangan terjadi sejak di pesemaian sampai terbentuknya anakan maksimun. Larva memakan jaringan mesofil daun dari permukaan bawah daun dan menyisahkan bagian epidermis pada bagian daun yang diserang dan tampak garisgaris memanjang berwarna keputihan, dan itu sebabnya hama ini disebut hama putih.

\section{Sesamia inferens Walker (Lepidoptera; Noctuidae)}

Imago berwarna ungu, pada sayap depan berwarna coklat keunguan, terdapat strep berwarna kehitaman, memanjang kebelakang. Sayap belakang berwarna putih. Ukuran tubuh berkisar $5-6$ mm (Gambar 4).

Serangan hampir sama dengan serangan Chilo suppressalis. Larva menyerang daun, pelepah dan batang. Serangan pada daun dan pelepah menyebabkan adanya bercak coklat daun dan pelepah, dan lama kelamaan menjadi kering. Serangan pada batang menyebabkan batang berlubang dan mudah patah. 


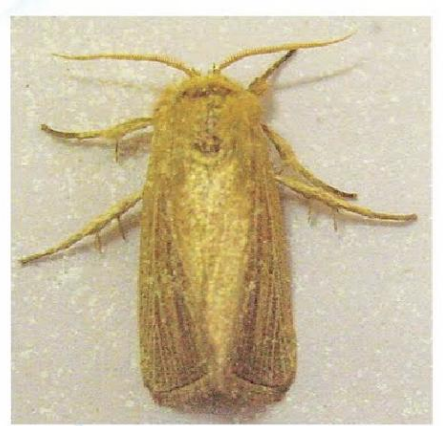

Gambar 4. Imago Sesamia inferens Walker

(Figure 4. The Adult of Sesamia inferens Walker)

\section{Nephotettix virescens Distant (Homoptera; Cicadellidae)}

Imago berwarna hijau dengan ujung sayap berwarna hitam kecoklatan. Panjang tubuh 2,5 - 3 mm (Gambar 5).

Hama ini merupakan hama sekunder dan dapat menularkan virus tungro dan virus kerdil rumput.

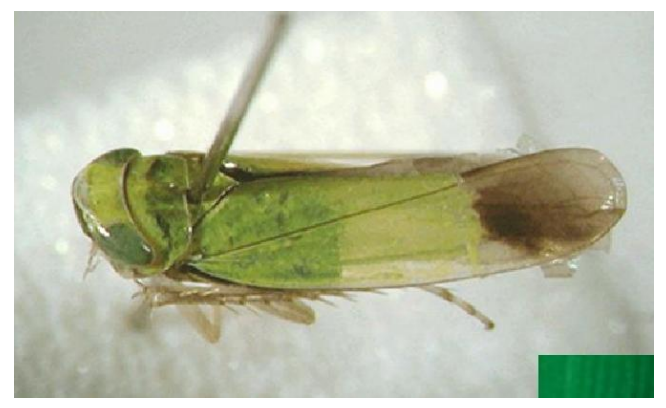

Gambar 5. Imago Nephotettix virescens

(Figure 5. The Adult of Nephotettix virescens)

\section{Nilaparvata lugen Stal. (Homoptera:}

Delphacidae).

Imago berwarna coklat sampai coklat kekuningan. Panjang tubuh 3 - 4 mm (Gambar 6). Nimfa dan imago menyerang tanaman padi sawah dan menularkan virus kerdil rumput dan jenis virus lainnya. Serangan berat dapat menyebabkan gejalah Hopperburn atau terbakar pada areal pertanaman padi sawah dan menyebabkan puso atau gagal total.

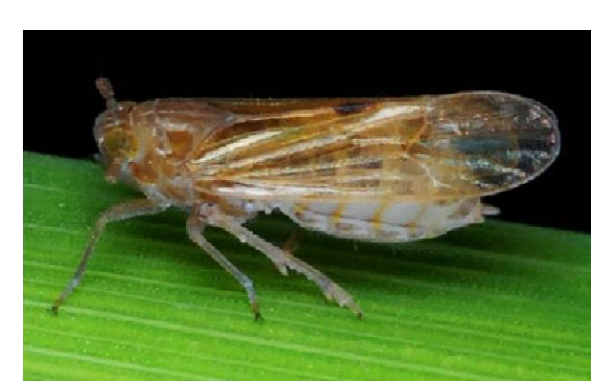

Gambar 6. Imago Nilaparvata lugen Stal

(Figure 6. The Adult of Nilaparvata lugen Stal)

\section{Leptocorisa oratorius Fab. (Hemiptera:} Alydidae)

Tubuh imago berbentuk memanjang atau lonjong, berwarna ada yang hijau dan coklat, atau hijau kecoklatan. Panjang tubuh $13-15,5 \mathrm{~mm}$ (Gambar 7).

Nimfa dan imago menyerang bulir padi yang masih muda menyebabkan bulir padi menjadi hampa. Bulir padi yang terserang biasanya berdiri tegak karena bulirnya tidak berisi atau hampa.

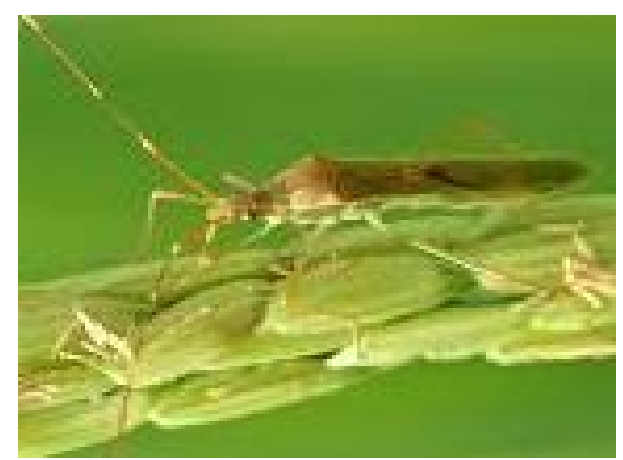

Gambar 7. Imago Leptocorisa oratorius Fab

(Figure 7. The Adult of Leptocorisa oratorius Fab)

\section{Pareaucosmetus sp (Hemiptera: Lygaeidae)}

Hama Pareucosmetus sp. yang dewasa berwarna hitam dan berbentuk memanjang dengan tubuh yang agak keras. Ukuran tubuh 8-12 mm (Gambar 8).

Hama ini menyerang tanaman padi sawah dengan menghisap cairan pada bulir padi baik yang masih muda maupun yang sudah hampir matang. Akibat dari serangan hama ini, menyebabkan bulir padi menjadi hampa atau kosong. Gejala serangan hama Pareucosmetus sp mirip dengan gejala se- 
ranggan Leptocorixa acutayaitu adanya bulir-bulir padi hampa dan bintik-bintik coklat sampai pada bulir-bulir yang sudah tua.

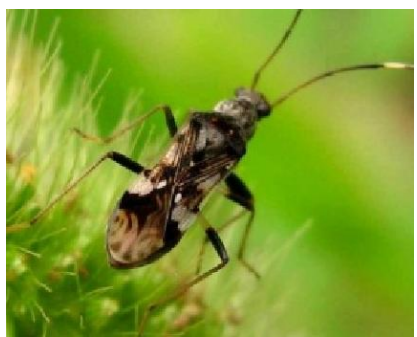

Gambar 8. Imago Pareaucosmetus sp.

(Figure 8. The Adult of Pareaucosmetus sp.)

\section{Sitophilus oryzae (Coleoptera: Curculionidae)} Imago berwarna hitam sampai hitam kecoklatan dan memiliki alat mulut berupa moncong/ rostrum. Sayap depan/elytra memiliki empat buah spot berbentuk bulat telur (lonjong) berwarna coklat kemerahan pada elytra dan kaki berwarna coklat kemerahan.

Di Indonesia dikenal dengan nama bubuk beras atau kumbang beras, di Sulawesi Utara disebut logong dan di Minahasa disebut lowong. Serangga ini merupakan hama pasca panen penting pada beras.

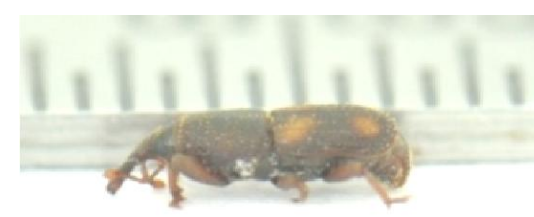

Gambar 9. Imago Sitophilus oryzae L.

(Figure 9. The Adult of Sitophilus oryzae L.)

\section{Pomacea canaliculata Lamarck (Mesogastropoda: Pilidae)}

Cangkang $P$. caniculata berbentuk seperti kerucut dari tabung yang melingkar, bagian yang terbuka disebut apertura yaitu tempat tersembulnya kaki dan kepala. Cangkang berwarna coklat kekuningan atau kuning keemasan sehingga namanya disebut keong emas (Gambar 10).

$P$. canculata merupakan herbivor polifag dan bersifat rakus, menyerang tanaman padi yang berusia muda yaitu sejak dari pesemaian hingga umur satu bulan setelah tanam. Gejala serangan ditandai dengan adanya bagian-bagian daun yang hilang pada anakan dan sebagian tercecer disekitar rumpun. Serangannya dapat mengakibatkan pertumbuhan terhambat sehingga produksi menurun. Serangan tertinggi terjadi sejak tanaman padi sawah umur 7 hari hingga 21 hari setelah tanam.

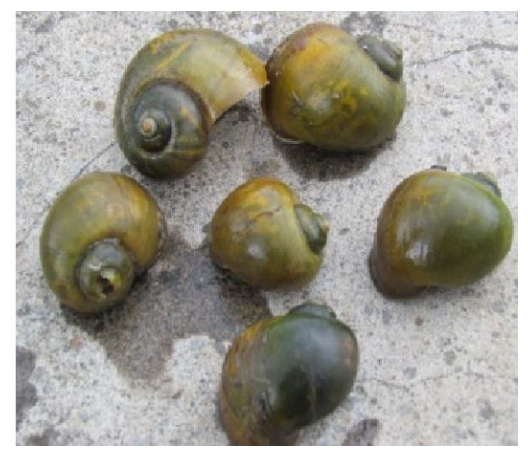

Gambar 10. Imago Pomacea caniculata Lamarck.

(Figure 10. The Adult of Pomacea caniculata Lamarck)

\section{Passer spp. (Passeriformes: Passeridae)}

Warna tubuh coklat kekuningan, sayap dan kepala berwarna coklat atau coklat kekuningan, tubuh bagian dada dan perut berwarna abu-abu keputihan. Ukuran tubuh bervariari yaitu 7,5-12 $\mathrm{cm}$.

Serangan hama burung terjadi pada fase vegetatif yaitu pada saat bulir padi sudah hampir matang/masak sanpai siap panen, bahkan sampai pasca panen.

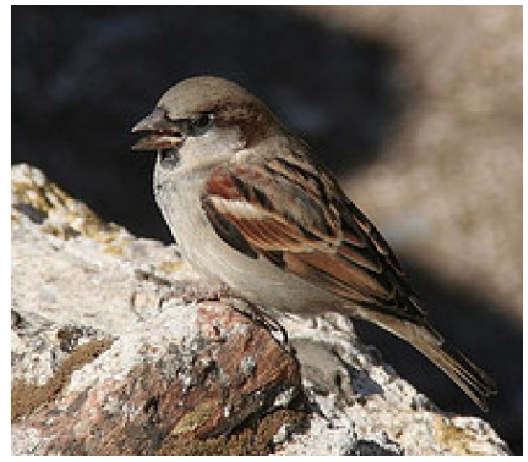

Gambar 11. Imago Passer spp.

(Figure 11. The Adult of Passer spp.)

\section{Rattus argentiventer Robinson and Kloss (Rodentia; Muridae).}

Hama tikus warnanya bervariasi dari coklat samapi caklat keabu-abuan. Ukuran juga bervariasi dari 20 - $35 \mathrm{~cm}$ (Gambar 12). 
Pathak (1977) mengemukakan bahwa kurang lebih 70 spesies hama yang merusak tanaman padi dan sekitar 20 spesis yang merupakan hama utama. Hama-hama tersebut menyerang akar, batang, daun, bunga, dan buah. Selanjutnya Kalshoven (1981) hama penting pada tanaman padi sawah yaitu penggerek batang padi bergaris (Chilo suppressalis), hama putih (Nymphula depunctalis), penggerek batang padi ungu (Sesamia inferens), penggerek batang padi kuning (Scirpophaga incertulas), wereng coklat (Nephotettix virescens), wereng hijau (Nilaparvata lugens), walang sangit (Leptocorisa acuta), pepinding tanah (Scotinophara coarctata), kepik hitam (Pareaucosmetus sp.), keong emas (Pomacea caniculata). Heinrichs (1994) menyatakan dari pembibitan sampai panen tanaman padi sawah diserang oleh beberapa hama penting yakni penggerek batang (Sesamia inferens, Chilo spp., Scirpophaga incertulas), hama putih (Nymphula depunctalis), hama wereng (Nephotettix virescens dan Nilaparvata lugens), walang sangit (Leptocorisa acuta), kepik hitam (Pareaucosmetus sp.), keong emas (Pomacea caniculata), hama burung (Passer spp.), dan hama tikus (Ratus-ratus spp.).

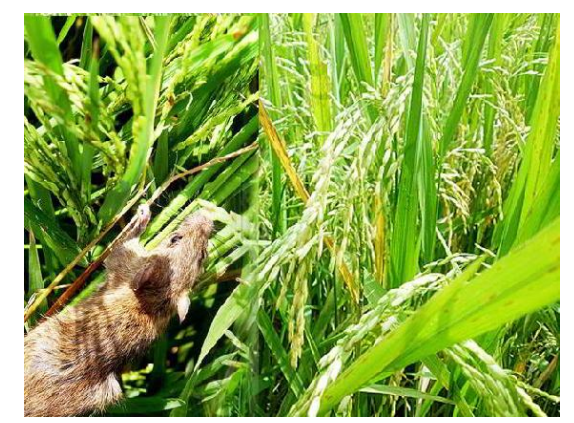

Gambar 12. Imago Rattus argentiventer

(Figure 12. The Adult of Rattus argentiventer)

\section{KESIMPULAN}

Hama-hama pada tanaman padi sawah di Kelurahan Makalonsow Kecamatan Tondano Timur Kabupaten Minahasa yaitu penggerek batang padi putih (Scirpophaga innotata), penggerek batang padi bergaris (Chilo suppressalis), hama putih (Nymphula depunctalis), penggerek batang padi ungu (Sesamia inferens), wereng coklat (Nephotettix virescens), wereng hijau (Nilaparvata lugens), walang sangit (Leptocorisa acuta), kepik hitam (Pareaucosmetus sp.), bubuk beras (Sitophilus oryzae), keong emas (Pomacea caniculata), hama burung padi sawah (Passer spp.), dan hama tikus padi sawah (Ratus argentiventer).

Selain hama, ditemukan juga organisme lain yang berperang sebagai musuh alami yaitu belalang sembah (Mantis sp.), capung (Sympetrum flaveolum), kumbang Coccinelid (Coccinella septempunctata), dan laba-laba pemburu (Pardosa $\mathrm{sp})$.

\section{DAFTAR PUSTAKA}

Flint, M.L. and van den Bosch. 1981. Introduction to Integrated Pest Management. Plenom Pre4ss. New York. $240 \mathrm{hlm}$.

Guntoro, S. 2011. Saatnya Menerapkan Pertanian Tekno-Ekologis. Sebuah Model Pertanian Masa Depan ntuk Menyikapi Perubahan Iklim. Penerbit : PT Agromedia Pustaka. Jagakarsa Jakarta Selatan.

Heinrichs, E.A. 1994. Biologi and Management of Rice Insects. IRRI. Wiley Eastern Limited, New Age International Limited. New Delhi. Bangalore. Bombay. Calcuta. Guwahati. Hyderabad. Lucknow. Madras. Pune. London. 779 hal.

Untung, K. 2001. Pengantar Pengelolaan Hama Terpadu. Gadjah Mada University Press. Universitas Gadjah mada. Yogyakarta.

Kalshoven, L.G.E. 1981. The Pests of Crops In Indonesia. PT. Ichtiar Baru Van Hoeve. Jakarta.

Oka Ida Nyoman. 1995. Pengendalian Hama Terpadu, dan Implementasinya di Indonesia. Gadjah Mada University Press. Yogyakarta 255 hal. 
Pathak, M.D. 1977. Insect Pest of Rice. The International Rice Research Institute, Los Banos, Philippines. $68 \mathrm{p}$

Pelealu, A. E. 2015. Adopsi Teknologi Pertanian Bagi Petani (Studi Fenomenologi Pada Petani Kelurahan Makalonsow Kecamatan Tondano Timur Kabupaten Minahasa). Disertasi. Program Pascasarjana Universitas Merdeka. Malang.

Roja, A. 2009. Pengendalian Hama dan Penyakit Secara Terpadu pada Tanaman Padi Sawah. Balai Pengkajian Teknologi Pertanian Sumatera Barat. Padang.
Sembel, D.T., J. Rimbing, M. Ratulangi, dan M. Meray. 2000. Pemantauan dan Peramalan Organisme PenggangguTanaman Pangan di Sulawesi Utara. Media Publikasi IImiah Pertanian Unsrat Eugenia Vol 6 No.4 April 2000. Manado.

Southwood, T.R.E. and M.J Woy. 1970. Ecologycal Background to Pest management in R.I. Rabb and E.E Guthrie (eds) Concep of Pest management North Caroline State University Releigh North Caroline.

Untung, K. 1993. Pengantar Pengelolaan Hama Terpadu. Gadajah Mada University Press, 